\title{
COMPARISON OF MORPHOLOGICAL TRAITS AND MINERAL CONTENT IN EUCOMIS AUTUMNALIS (MILL.) CHITT. PLANTS OBTAINED FROM BULBS TREATED WITH FUNGICIDES AND COATED WITH NATURAL POLYSACCHARIDES
}

\author{
Piotr Salachna ${ }^{1}$, Agnieszka Zawadzińska $^{1}$ \\ 1 Department of Horticulture, Faculty of Environmental, Management and Agriculture, West Pomeranian \\ University of Technology in Szczecin, Papieża Pawła VI 3, 71-459 Szczecin, Poland, e-mail: piotr.salachna@zut. \\ edu.pl; agnieszka.zawadzinska@zut.edu.pl
}

Received: 2014.12.24

Accepted: 2015.02.04

Published: 2015.04.01

\begin{abstract}
Eucomis autumnalis is an attractive ornamental species from the South Africa, commonly used in natural medicine. Plant protection programs, particularly those concerning plants grown for phytotherapeutics, are focused on prophylactic treatments that facilitate a limited use of pesticides negatively affecting the environment. Polysaccharides, such as chitosan and sodium alginate are exemplary non-toxic and biodegradable substances used for hydrogel coatings. The aim of this study was to investigate the effects of treating E. autumnalis bulbs with fungicide or coating with natural polysaccharides on the morphological traits and content of minerals in the leaves and bulbs. Prior to planting, the bulbs were divided into three groups: (I) untreated bulbs (control); (II) bulbs treated with Kaptan and Topsin fungicides; (III) bulbs coated with oligochitosan and sodium alginate. Bulb coating was found to exert a stimulating effect on plant height, number and length of leaf, greenness index (SPAD), number of flowers per inflorescence, fresh weight of the aboveground part and fresh weight of bulbs. The leaves and bulbs of plants grown from coated bulbs contained more nitrogen, potassium and boron. Treating the bulbs with fungicides positively affected the number of leaves, greenness index and fresh weight of the aboveground part.
\end{abstract}

Keywords: pineapple lily, oligochitosan, sodium alginate, macronutrients, micronutrients.

\section{INTRODUCTION}

Synthetic fungicides used in plant protection have a negative impact on the environment, and therefore, environmentally-friendly solutions based on non-toxic and biodegradable substances are sought for. Some examples of environmentally-safe compounds are natural polysaccharides, of which chitosan and its derivatives are particularly promising [1]. Chitosan is a polymer obtained by N-deacetylation of natural chitin. It is a linear polymer containing D-glucosamine $(\mathrm{GlcN})$ and $\mathrm{N}$-acetyl-D-glucosamine (GlcNAc) molecules linked by $\beta-1,4-$ glycosidic bonds [2]. It is used in agriculture and horticulture, mainly as an elicitor of resistance to certain pathogenic infections and as a growth stimulator [3]. In plants, chitosan can stimulate seed germination [4], accelerate flowering [5], increase chlorophyll content [6], and plant tolerance to stress [7], and improve yield quantity and quality [8]. Another natural polymer that can be potentially used in plant cultivation is sodium alginate. It is composed of $\beta-1,4$ linked $\beta$-D-mannuronic acid and $\alpha$-L-guluronic acid. On the industrial scale, alginates are extracted from brown algae, mainly Laminaria and Lessonia [9]. Sodium alginate, particularly in the form of depolymerized oligosaccharide, was reported to have a stimulating effect on the growth in several plants, such as mint [10], fennel [11], and potato [12]. Natural polysaccharides can be used for coating formation on the surface of plant organs [13].

Eucomis autumnalis (Mill.) Chitt., also known as "pineapple lily", is an original bulbous 
plant of Asparagaceae family, native to southern Africa. The plants have very decorative raceme inflorescences composed of numerous, starshaped, greenish-white and sweetly scented flowers. This species can be grown as garden plants, cut flowers and flowering potted plants, with high demand by the European and North American markets [14]. Due to antibacterial and antifungal compounds, the bulbs of E. autumnalis are used in southern African traditional medicine [15]. The anti-inflammatory activity in E. autumnalis plant depends on age, season, fertilization and growth conditions [16]. The subject literature lacks data on E. autumnalis cultivation in the Central European climatic conditions, which is a problem for the producers of ornamental and medicinal plants interested in wider use of this species. So far, no information has been published on the use of natural polysaccharides for encapsulation of E. autumnalis bulbs before planting. Therefore, the aim of this study was to evaluate growth, development and the content of minerals in $E$. autumnalis plants grown from the bulbs treated with traditional fungicides and from the bulbs coated with oligochitosan and sodium alginate.

\section{MATERIAL AND METHODS}

\section{Plant material and treatments}

The study was conducted at a research plot of the West Pomeranian University of Technology in Szczecin $\left(53^{\circ} 25^{\prime} \mathrm{N}, 14^{\circ} 32^{\prime} \mathrm{E} ; 25 \mathrm{~m}\right.$ asl.). Study material were E. autumnalis bulbs, $14-16 \mathrm{~cm}$ in circumference, obtained from Dutch plantations. Prior to planting, the bulbs were divided into three groups: (I) non-treated control bulbs; (II) bulbs treated for $30 \mathrm{~min}$ with fungicide suspension 1.0\% (w/v) Kaptan 50 WP (active ingredient: Captan) and $0.7 \%(\mathrm{w} / \mathrm{v})$ Topsin M 500 SC (active ingredient: thiophanate-methyl); (III) bulbs coated as described by Startek et al. [17] in $0.2 \%$ (w/v) oligochitosan and $1 \%(\mathrm{w} / \mathrm{v})$ sodium alginate (Sigma Aldrich). Oligochitosan $\left(\mathrm{M}_{\mathrm{w}} 48000 \mathrm{~g} \cdot \mathrm{mol}^{-1}\right.$; DD $85 \%$ ) was purchased from Center of Bioimmobilisation and Innovative Packaging Materials (Szczecin, Poland). The products have been obtained using the free radical degradation process [18].

\section{Growth conditions and plant measurements}

The bulbs were planted on $15^{\text {th }}$ April 2012 and $17^{\text {th }}$ April 2013, into polyethylene boxes
$60 \times 40 \times 19 \mathrm{~cm}$, filled with deacidified peat (Kronen, Poland), $\mathrm{pH}$ 6.0, with mean content of macronutrients amounting to $11 \mathrm{mg} \cdot \mathrm{dm}^{-3} \mathrm{~N}_{-N_{3}}$, $39 \mathrm{mg} \cdot \mathrm{dm}^{-3} \mathrm{P}$, and $13 \mathrm{mg} \cdot \mathrm{dm}^{-3} \mathrm{~K}$. The substrate was supplemented with multicomponent fertilizer Hydrocomplex (Yara International ASA, Norway) at a dose of $5 \mathrm{~g} \cdot \mathrm{dm}^{-3}$ that contained $12 \% \mathrm{~N}, 11 \% \mathrm{P}_{2} \mathrm{O}_{5}, 18 \% \mathrm{~K}_{2} \mathrm{O}, 2.7 \% \mathrm{MgO}, 8 \% \mathrm{~S}$, $0.015 \% \mathrm{~B}, 0.2 \% \mathrm{Fe}, 0.02 \% \mathrm{Mn}$, and $0.02 \% \mathrm{Zn}$. Each box contained 8 bulbs, planted at a spacing of $10 \times 10 \mathrm{~cm}$. The plants were grown in an unheated plastic tunnel, under natural photoperiod. Air temperature was controlled with vents that were opened when the temperature exceeded $20{ }^{\circ} \mathrm{C}$. The plants were cultivated according to agrotechnical standards developed for Eucomis by the International Flower Bulb Centre [19]. When the plants reached the full bloom stage, the following parameters were evaluated: plant height, leaf number and length, inflorescence length, and number of flowers per inflorescence. Leaf greenness index that highly correlates with chlorophyll content was determined using Chlorophyll Meter SPAD-502 (Minolta, Japan). This evaluation is based on determining the quotient of difference in light absorption by a leaf at $650 \mathrm{~nm}$ and 940 $\mathrm{nm}$. The result is given in dimensionless units called SPAD. Mean SPAD value was calculated based on four readings of four leaves from each plant. The plants were dug out in both years of the study on $20^{\text {th }}$ October and the aboveground part and bulbs were weighted.

\section{Determination of mineral content}

The content of macro- and micronutrients in the bulbs and leaves obtained at full anthesis was analyzed in a laboratory. To this end, 8 plants from each variant were randomly dug out, and the maternal bulbs without roots and fully developed leaf blades were separated. Chemical analyzes were carried out in dried at $105{ }^{\circ} \mathrm{C}$ material, according to the standards of an accredited laboratory of the Chemical and Agricultural Station in Szczecin. The mineralized plant material was used for the determination of nitrate nitrogen by means of a colorimetric method, potassium and calcium by means of the atomic emission spectrometry (Solaar S AA spectrometer), phosphorus content was evaluated based on Baton method on Marcel s 330 PRO spectrophotometer at a wavelength $\lambda=470 \mathrm{~nm}$, and magnesium and micronutrient (B, $\mathrm{Cu}, \mathrm{Fe}, \mathrm{Mn}, \mathrm{Zn})$ content were measured 
by means of the flame atomic absorption spectroscopy using Solaar S AA spectrometer [20].

\section{Statistical analysis}

The study was designed as a univariate experiment involving randomized sub-blocks, with four replications comprising 8 plants each. The results were verified statistically by means of one-way analysis of variance (ANOVA), using FR-ANALWAR software developed by Professor Franciszek Rudnicki of the University of Science and Technology in Bydgoszcz. Significance of mean values variation was assessed by Tukey's multiple comparison test at $\mathrm{p}=0.05$.

\section{RESULTS AND DISCUSSION}

Statistical analysis of the experimental results revealed that the treatment of E. autumnalis bulbs before planting significantly affected most of the evaluated traits (Table 1). It was found that the plants obtained from the bulbs coated with oligochitosan and sodium alginate were the highest $(35.2 \mathrm{~cm})$, had the longest leaves $(27.9 \mathrm{~cm})$, the highest number of flowers per inflorescence (75.0), and the greatest fresh weight of the aboveground part (126 g) and dug out bulbs (43.5 g). Additionally, a positive effect of coatings containing natural polysaccharides was observed with reference to the number of leaves and their greenness index expressed in SPAD units, by respectively $15.0 \%$ and $10.5 \%$, as compared to the control plants. Previous studies $[5,17]$ showed positive effects of coating freesia (Freesia hybrida) bulbs with polysaccharides on the morphological characteristics of plants, flowering and corms yield, with type of polymer and molecular weight of chitosan significantly affecting these traits. Several studies suggested that chitosan stimulates the vegetative growth and the developing of roots and shoots and improves the efficiency of nutrient and water uptake, which can be beneficial for plant growth $[21,22]$. Apart from oligochitosan, the coatings investigated in our study included also sodium alginate, which is another biostimulator exerting positive effects on plant metabolism. According to Khan et al. [23], treating opium poppy plants (Papaver somniferum L.) with oligo-alginates at the doses of 0.02 to $0.1 \mathrm{mg} \cdot \mathrm{ml}^{-1}$, improved root and shoot length, dry weight, and total content of chlorophylls, carotenoids and alkaloids, including codeine and morphine. In fennel (Foeniculum vulgare Mill.), oligo-alginates positively affected the activity of nitrate reductase, plant growth and development, seed yield, and the content of assimilation pigments, proline and essential oils [24].

The plants derived from the bulbs treated with a mixture of Kaptan and Topsin had significantly more leaves, higher greenness index and greater mass of the aboveground part, by respectively $10.0 \%, 11.0 \%$ and $11.6 \%$, as compared to the control (Table 1). A positive impact of Captan $50 \mathrm{WP}$, a formulation containing the same active substance as Kaptan used in this study, was also found in some ornamental geophytes. Piskornik et al. [25] showed that, apart from protective properties, the fungicide affected also the quality and yield of Ixia hybrida L. flowers. The plants grown from bulbs treated with $2 \%$ Captan solution produced the highest number of flowers. Furthermore, the yield of daughter bulbs derived from plants grown from treated bulbs was the most abundant and of the highest quality [25]. Klimek et al. [26] also reported that buttercup (Ranunculus asiaticus L.) bulbs treated with $2 \%$ Captan $50 \mathrm{WP}$ for 30 minutes produced plants with more flowers and of greater mass than non-treated control bulbs.

Table 1. Effect of fungicides and polysaccharides on morphological traits of Eucomis autumnalis (means for 2012-2013)

\begin{tabular}{|c|c|c|c|}
\hline \multirow{2}{*}{ Traits } & \multicolumn{3}{|c|}{ Treatment of bulbs before planting } \\
\hline & non-treated (control) & dressed with fungicides & coated with polysaccharides \\
\hline Height of plant (cm) & $30.7^{b}$ & $33.7 \mathrm{ab}$ & $35.2^{a}$ \\
\hline Number of leaves & $5.00^{b}$ & $5.50^{a}$ & $5.75^{a}$ \\
\hline Lenght of leaf (cm) & $22.2^{c}$ & $24.1^{b}$ & $27.9^{a}$ \\
\hline Greenness index of leaves (SPAD) & $39.0^{b}$ & $43.3^{a}$ & $43.1^{a}$ \\
\hline Length of inflorescence $(\mathrm{cm})$ & $14.5^{\mathrm{a}}$ & $17.4^{a}$ & $16.3^{a}$ \\
\hline Number of flowers per inflorescence & $64.0^{b}$ & $66.0^{b}$ & $75.0^{a}$ \\
\hline Fresh weight of aboveground part (g) & $90.5^{c}$ & $101^{\mathrm{b}}$ & $126^{a}$ \\
\hline Fresh weight of bulb (g) & $36.1^{b}$ & $40.7^{a b}$ & $43.5^{a}$ \\
\hline
\end{tabular}

Values in the same row followed by the same letter do not differ significantly. 
The way of treating E. autumnalis bulbs prior to planting significantly affected plant content of two macronutrients, nitrogen and potassium. No relationships were observed between bulb treatment and the content of phosphorus, magnesium and calcium in the leaves and bulbs (Table 2). The bulbs coated with chitosan and sodium alginate produced plants whose leaves contained the highest amount of nitrogen and potassium. The lowest content of nitrogen and potassium in the leaves was found in the plants grown from control bulbs. Nitrogen is an essential element of amino acids and, as a component of these and many other compounds, it is involved in almost all biochemical reactions in the plant tissues. Potassium is a key ion, the concentration of which determines the value of osmotic potential [27]. Increased leaf content of macronutrients as an effect of chitosan treatment was also observed by Dzung et al.
[21]. These researchers sprayed coffee seedlings, grown in the field and in a greenhouse, with solutions of chitosan and its oligomers at a concentration of 20-80 ppm. Following application of chitosan oligomers, the coffee seedlings grown in the field contained more nitrogen, phosphorus, potassium, calcium and magnesium, respectively by $9.49 \%, 11.76 \%, 0.98 \%, 18.75 \%$ and $3.77 \%$ than the control plants. Similar results regarding significant effect of chitosan on the mineral content in plants were obtained by Nguyen Van et al. [28]. They proved that spraying coffee seedlings with chitosan nanoparticles of high molecular weight, resulted in increased uptake of macronutrients by plants, by $9.8-27.4 \%$ for $\mathrm{N}, 17.3-30.4 \%$ for $\mathrm{P}$, and $30-45 \%$ for $\mathrm{K}$.

An analysis of micronutrients revealed significant differences in the content of boron and iron, depending on the treatment of E. autumna-

Table 2. Effect of fungicides and polysaccharides on macronutrients concentration in the leaves and bulbs of $E u$ comis autumnalis (means for 2012-2013)

\begin{tabular}{|c|c|c|c|c|}
\hline \multirow{2}{*}{$\begin{array}{c}\text { Macronutrient content } \\
(\% \mathrm{DW})\end{array}$} & \multirow{2}{*}{ Plant organ } & \multicolumn{3}{|c|}{ Treatment of bulbs before planting } \\
\hline & & non-treated (control) & dressed with fungicides & coated with polysaccharides \\
\hline \multirow{2}{*}{ Nitrogen } & leaves & $2.65^{c}$ & $2.96^{b}$ & $3.22^{a}$ \\
\hline & bulbs & $0.45^{b}$ & $0.51^{b}$ & $0.69^{a}$ \\
\hline \multirow{2}{*}{ Phosphorus } & leaves & $0.22^{a}$ & $0.19^{a}$ & $0.20^{a}$ \\
\hline & bulbs & $0.05^{a}$ & $0.07^{a}$ & $0.04^{a}$ \\
\hline \multirow{2}{*}{ Potassium } & leaves & $2.58^{c}$ & $3.28^{b}$ & $4.13^{a}$ \\
\hline & bulbs & $0.38^{b}$ & $0.49^{a}$ & $0.52^{a}$ \\
\hline \multirow{2}{*}{ Calcium } & leaves & $2.29^{a}$ & $2.55^{a}$ & $2.61^{a}$ \\
\hline & bulbs & $0.15^{a}$ & $0.19^{a}$ & $0.14^{a}$ \\
\hline \multirow{2}{*}{ Magnesium } & leaves & $0.14^{a}$ & $0.17^{a}$ & $0.18^{a}$ \\
\hline & bulbs & $0.04^{a}$ & $0.03^{a}$ & $0.04^{a}$ \\
\hline
\end{tabular}

$\mathrm{DW}=$ dry weight. Date are means of triplicate. Values in the same row followed by the same letter do not differ significantly.

Table 3. Effect of fungicides and polysaccharides on micronutrients concentration in the leaves and bulbs of Eucomis autumnalis (means for 2012-2013)

\begin{tabular}{|c|c|c|c|c|}
\hline \multirow{2}{*}{$\begin{array}{c}\text { Micronutrient content } \\
(\mathrm{mg} / \mathrm{kg} \mathrm{DW})\end{array}$} & \multirow{2}{*}{ Plant organ } & \multicolumn{3}{|c|}{ Treatment of bulbs before planting } \\
\cline { 2 - 5 } & leaves & $21.0^{\mathrm{c}}$ & $25.0^{\mathrm{b}}$ & $39.1^{\mathrm{a}}$ \\
\hline \multirow{2}{*}{ Boron } & bulbs & $6.47^{\mathrm{c}}$ & $9.10^{\mathrm{b}}$ & $13.3^{\mathrm{a}}$ \\
\cline { 2 - 5 } & leaves & $3.02^{\mathrm{a}}$ & $3.45^{\mathrm{a}}$ & $2.97^{\mathrm{a}}$ \\
\hline \multirow{2}{*}{ Copper } & bulbs & $6.30^{\mathrm{a}}$ & $5.13^{\mathrm{a}}$ & $4.72^{\mathrm{a}}$ \\
\cline { 2 - 5 } & leaves & $70.1^{\mathrm{b}}$ & $68.7^{\mathrm{b}}$ & $85.5^{\mathrm{a}}$ \\
\hline \multirow{2}{*}{ Iron } & bulbs & $34.6^{\mathrm{a}}$ & $38.7^{\mathrm{a}}$ & $38.0^{\mathrm{a}}$ \\
\cline { 2 - 5 } & leaves & $38.2^{\mathrm{a}}$ & $47.8^{\mathrm{a}}$ & $6.48^{\mathrm{a}}$ \\
\hline \multirow{2}{*}{ Manganese } & bulbs & $5.61^{\mathrm{a}}$ & $7.55^{\mathrm{a}}$ & $37.0^{\mathrm{a}}$ \\
\cline { 2 - 5 } & leaves & $36.8^{\mathrm{a}}$ & $32.0^{\mathrm{a}}$ & $26.0^{\mathrm{a}}$ \\
\hline \multirow{2}{*}{ Zinc } & bulbs & $21.0^{\mathrm{a}}$ & $19.0^{\mathrm{a}}$ & coated with polysaccharides \\
\hline
\end{tabular}

$\mathrm{DW}=$ dry weight. Date are means of triplicate. Values in the same row followed by the same letter do not differ significantly. 
lis bulbs before planting. Bulb treating or coating had no influence on the content of manganese, zinc and copper in the leaves and bulbs or iron in the bulbs (Table 3). The highest content of boron, both in the leaves and bulbs, was found in the plants grown from coated bulbs. The lowest concentration of boron in the leaves and bulbs was found in the control plants. Boron is involved in the formation of cell wall structures, plant growth, and indirectly in carbohydrate metabolism. Monocotyledon plants, including E. autumnalis, are characterized by lower boron requirements than dicotyledons [27]. Our experiment showed that the leaves of plants grown from coated bulbs contained significantly more iron than the plants grown from fungicide-treated or control bulbs. The leaves of plants grown from coated bulbs had greater greenness index correlated with chlorophyll content, which was most likely due to an increased iron concentration in the leaves. Iron is involved in the synthesis of chlorophyll and some proteins and serves as an electron carrier in redox reactions [27]. Chatelian et al. [29] investigated the effects of chitooligosaccharides (COS) on growth and accumulation of minerals in beans (Phaseolus vulgaris L.) grown in hydroponic conditions and reported diverse micronutrient content in plants treated with chitosan. It was found that chitosan application significantly changed the accumulation of such micronutrients as molybdenum, boron, manganese, iron, copper, sodium, zinc, lead and cadmium by the roots, stems and leaves. Therefore, it can be assumed that chitosan may affect the absorption and accumulation of individual elements by plant tissues.

An analysis of the nutrient content in different parts of the plants indicated that the leaves contained more nitrogen, phosphorus, potassium, calcium, magnesium, boron, zinc, manganese, and iron than the bulbs, which, in turn, contained more copper (Table 2-3). The available literature contains no data on the limiting values defining an optimal range of nutrients for Eucomis species and cultivars. The results of the analyzes for the plants may be useful in the development of fertilization schedules for the studied species.

The agricultural industry has recently showed an increasing interest in new, environmentallyfriendly technologies aimed at protecting specific biological materials against negative effects of direct contact with the external environment. Coating seeds, cuttings, bulbs and corms in hydrogel seems to be a particularly promising method
$[30,31]$. The present study employed a patented method based on the formation of polyelectrolyte complexes [13]. These complexes are formed by an interaction of anionic functional groups of the polyelectrolyte with polyvalent metal cations, or by reaction at the interface of aqueous solutions of polyelectrolytes with functional groups of opposite charges. Raw materials used for coating bulbs in this study included two polysaccharides, oligochitosan and sodium alginate. These compounds are safe for humans, they do not pollute the environment, and help us to reduce the use of harmful chemicals in the agriculture and horticulture.

\section{CONCLUSIONS}

Oligochitosan and sodium alginate can be successfully used in practice for the preparation of hydrogel coatings for the bulbs of E. autumnalis. Bulb coating had beneficial effect on most morphological traits of the plants, such as height, number and length of leaf, greenness index, number of flowers per inflorescence, fresh weight of the aboveground part and fresh weight of bulbs. Moreover, the leaves and bulbs contained more nitrogen, potassium and boron. Data on the production technology of E. autumnalis in the Central European climatic conditions are lacking, and thus the results of this study may be a valuable source of information for producers of ornamental and herbal plants interested in cultivation of this species.

\section{Acknowledgments}

The research was supported by the by the Polish National Science Centre (project 7778/B/ P01/2011/40).

\section{REFERENCES}

1. Cabrera J.C., Wégria G., Onderwater R.C.A., González G., Nápoles M.C., Falcón-Rodríguez A.B., Costales D., Rogers H.J, Diosdado E., González S., Cabrera G., González L, Wattiez R. 2013. Practical use of oligosaccharins in agriculture. Acta Horticulturae 1009, 195-211.

2. Deepmala K., Hemantaranjan A., Bharti S., Nishant Bhanu A. 2014. A future perspective in crop protection: Chitosan and its oligosaccharides. Advances in Plants and Agriculture Research 1(1), 1-8.

3. Hadwiger L.A. 2013. Plant science review: Multiple effects of chitosan on plant systems: Solid science or hype. Plant Science 208, 42-49. 
4. Al-Tawaha A.R.M., Al-Ghzawi A.L.A. 2013. Effect of chitosan coating on seed germination and salt tolerance of Lentil (Lens culinaris L.). Research on Crops 14 (2), 489-491.

5. Salachna P., Zawadzińska A. 2014. Effect of chitosan on plant growth, flowering and corms yield of potted freesia. Journal of Ecological Engineering 15(3), 97-102.

6. Zahid N., Ali A., Manickam S., Siddiqui Y., Alderson P.G., Maqbool M. 2014. Efficacy of curative applications of submicron chitosan dispersions on anthracnose intensity and vegetative growth of dragon fruit plants. Crop Protection 62, 129-134.

7. Jabeen N., Ahmad R. 2013. The activity of antioxidant enzymes in response to salt stress in safflower (Carthamus tinctorius L.) and sunflower (Helianthus annuus L.) seedlings raised from seed treated with chitosan. Journal of the Science of Food and Agriculture 93(7), 1699-1705.

8. Salachna P., Wilas J., Zawadzińska P. 2014. The effect of chitosan coating of bulbs on the growth and flowering of Ornithogalum saundersiae Baker. Proceedings of the 29th International Horticultural Congress: Sustaining Lives, Livelihoods and Landscapes (Aug. 17-22), Brisbane, Australia.

9. Bixler H.J., Porse H. 2011. A decade of change in the seaweed hydrocolloids industry. Journal of Applied Phycology 23, 321-335.

10. Naeem M., Idrees M., Aftab T., Khan M.M.A., Moinuddin, Varshney L. 2011. Irradiated sodium alginate improves plant growth, physiological activities and active constituents in Mentha arvensis L. Journal of Applied Pharmaceutical Science (2) 5, 28-35.

11. Sarfaraz A., Naeem M., Nasir S., Idrees M., Aftab T., Hashmi N., Khan M.A.A., Varshney M., Varshney L. 2011. An evaluation of the effects of irradiated sodium alginate on the growth, physiological activities and essential oil production of fennel (Foeniculum vulgare Mill.). Journal of Medicinal Plants Research 5, 15-21.

12. Hussein O.S., Hamideldin N. 2014. Effects of spraying irradiated alginate on Solanum tuberosum L. plants: Growth, yield and physiological changes of stored tubers. Journal of Agriculture and Veterinary Science (7)1, 75-79.

13. Bartkowiak A., Startek L., Żurawik P., Salachna P. 2008. Sposób wytwarzania otoczek hydrożelowych na powierzchni organów roślinnych. Patent PL Nr 197101.

14. Luria G., Ziv O., Weiss D. 2011. Effects of temperature, day length and light intensity on Eucomis development and flowering. Acta Horticulturae 886, 167-174.

15. Masondo N.A., Finnie J.F., Van Staden J. 2014. Pharmacological potential and conservation prospect of the genus Eucomis (Hyacinthaceae) en- demic to southern Africa. Journal of Ethnopharmacology 151, 44-53.

16. Taylor J.L.S., van Staden J. 2001. The effect of age, season and growth conditions on anti-inflammatory activity in Eucomis autumnalis (Mill.) Chitt. Plant extracts. Plant Growth Regulation 34(1), 39-47.

17. Startek L., Bartkowiak A., Salachna P., Kamińska M., Mazurkiewicz-Zapałowicz K. 2005. The influence of new method of corm coating on freesia growth, development and health. Acta Horticulturae 673, 611-616.

18. Bartkowiak A. 2001. Binary polyelectrolyte microcapsules based on natural polysaccharides. Wydawnictwo Politechniki Szczecińskiej, Szczecin.

19. Anonymous 1995. Information on special bulbs. International Flower Bulb Center, Hillegom, The Netherlands.

20. Ostrowska A., Gawliński S., Szczubiałka Z. 1991. Metody analizy i oceny właściwości gleb i roślin. Instytut Ochrony Środowiska, Warszawa.

21. Dzung N.A., Khanh V.T.P., Dzung T.T. 2011. Research on impact of chitosan oligomers on biophysical characteristics, growth, development and drought resistance of coffee. Carbohydrate Polymers 84, 751-755.

22. Rahman M.M., Kabir S., Rashid T.U., Nesa B., Nasrin R., Haque P., Khan M.A. 2013. Effect of $\gamma$-irradiation on the thermomechanical and morphological properties of chitosan obtained from prawn shell: Evaluation of potential for irradiated chitosan as plant growth stimulator for Malabar spinach. Radiation Physics and Chemistry 82, 112-118.

23. Khan Z.A, Khan M.M.A., Aftab T., Idrees M., Naeem M. 2011. Influence of alginate oligosaccharides on growth, yield and alkaloid production of opium poppy (Papaver somniferum L.). Frontiers of Agriculture in China 5, 122-127.

24. Idrees M., Naeem M., Aftab T., Hashmi N., Khan M.M.A., Varshney M., Varshney L. 2012. Promotive effect of irradiated sodium alginate on seed germination characteristics of fennel (Foeniculum vulgare Mill.). Journal of Physiology and Biochemistry (8) 1, 108-113.

25. Piskornik M., Kurzawińska H., Klimek A. 2001. Wpływ fungicydów użytych do zaprawiania bulw na zdrowotność i plonowanie iksji ogrodowej (Ixia $\times$ hybrida L.) uprawianej pod osłonami. Zeszyty Naukowe Akademii Rolniczej im. H. Kołłątaja w Krakowie 379, 149-154.

26. Klimek A., Piskornik M. Kurzawińska H. 2001. Wpyw wybranych fungicydów na rośliny jaskra azjatyckiego (Ranunculus asiaticus L.). Zeszyty Naukowe Akademii Rolniczej im. H. Kołłątaja w Krakowie 379, 105-109.

27. Kopcewicz J., Lewak S. 2007. Fizjologia roślin. Wydawnictwo Naukowe PWN, Warszawa. 
28. Nguyen Van S., Dinh Minh H., Nguyen Anh D. 2013. Study on chitosan nanoparticles on biophysical characteristics and growth of Robusta coffee in green house. Biocatalysis and Agricultural Biotechnology 2(4), 289-294.

29. Chatelain P.G., Pintado M.E., Vasconcelos M.W. 2014. Evaluation of chitooligosaccharide application on mineral accumulation and plant growth in Phaseolus vulgaris. Plant Science DOI: 10.1016/j. plantsci.2013.11.009.
30. Salachna P., Zawadzińska A. 2014. Optimization of Ornithogalum saundersiae Baker propagation by twin scale cuttings with the use of biopolymers. Journal of Basic and Applied Sciences 10, 514-518.

31. Salachna P., Zawadzińska P., Wilas J. 2014. The use of natural polysaccharides in Eucomis autumnalis (Mill.) Chitt. propagation by twin-scale cuttings. Proceedings of the 29th International Horticultural Congress: Sustaining Lives, Livelihoods and Landscapes (Aug. 17-22), Brisbane, Australia. 